Original Research Article

\title{
Pattern of self-medication amongst housewives vs working women in urban population in Southern Rajasthan
}

\author{
Meena Atray, Radhika Vijay*
}

Department of Pharmacology, Ravindra Nath Tagore Medical College, Udaipur, Rajasthan, India

Received: 21 May 2018 Accepted: 26 June 2018

*Correspondence to:

Dr. Radhika Vijay,

Email: drradhika_vijay@ yahoo.in

Copyright: () the author(s), publisher and licensee Medip Academy. This is an openaccess article distributed under the terms of the Creative Commons Attribution NonCommercial License, which permits unrestricted noncommercial use, distribution, and reproduction in any medium, provided the original work is properly cited.

\begin{abstract}
Background: The use of medications without prior medical consultation regarding indication, dosage, and duration of treatment is referred to as selfmedication1. Self-medication has its own benefits regarding reduction in load and cost of medical services. Women are primarily responsible for the health needs of the family and self- medication is frequently practiced by them. Working environment may influence the attitude of women towards safe and rational selfmedication. This study focuses on the pattern and attitude of women (housewives/ working) towards self- medication and influence of working atmosphere and exposure of women on self-medication.

Methods: 170 women of age group 18-60 years were included in the study and after taking permission from Institutional ethics committee. Data was collected by making the participants fill a semi structured detailed questionnaire under observation of instructor. The data was analysed using Microsoft excel and compared by using Fischer exact test.

Results: Most common ailment for which self-medication was practiced was pain. Working women primarily used pharmacist and house wives use old experience and family friends as primary source of information. Working women were more cautious about adverse drug reactions, drug-drug interactions, expiry date of medicine, reading instruction manual, use of counterfeit medicine and referring the experience to their known subjects as compare to housewives.

Conclusions: Self-medication was prevalent in both the groups, though working environment has positive influence towards safe, responsible and rational selfmedication. There is need for education regrading safe use of medicine and strict rules and regulations for availability of drugs.
\end{abstract}

Keywords: Housewives, Self-medication, Working women

\section{INTRODUCTION}

The use of medications without prior medical consultation regarding indication, dosage, and duration of treatment is referred to as self-medication ${ }^{1}$ Self-medication has its own benefits regarding reduction in load and cost of medical services. ${ }^{1}$ World medical association states that there are two types of medicines- prescription and nonprescription. ${ }^{2}$ Former are available on prescription from physician. They have many complications such as toxicity, various ADRs. ${ }^{3,4}$ Latter are over the counter drugs not requiring physician's consultation and their usage is known as Responsible selfmedication. ${ }^{5}$ It's different from irresponsible use of buying and using prescribed medicine without physician consultation. This practice is hazardous for self. There is need for positive attitude, more information regarding this. It is very alarming to know that many drugs previously restricted to prescription only are being provided as over the counter drugs. Various governmental health policies support the public to exercise greater role in their own treatment. ${ }^{6,7}$ 
It has simply led to greater hazards of ADRs and drug-drug interactions. ${ }^{8}$ In India, there are innumerable small drug shops in urban, suburban areas which are entangled in competition and provide over the counter drugs. This habit has been fatal many times, hence public should be properly educated about dangers of indiscriminate use of drugs. World Health Organization has emphasized that selfmedication must be correctly taught and controlled., ${ }^{9,10}$

Women mainly are the safe keepers of their family health and they purchase medications, take care of their children and sometimes take their older parents to health care providers and tend to make most of the family health care decisions. ${ }^{11}$

It is evident that women display more symptoms from acute and chronic conditions than men do, although their conditions are probably less threatening than men. ${ }^{12}$ This enhanced frequency of display of symptoms amongst women lead to more drug use (WHO 1993) mostly results are desired outcomes, but mishaps are not uncommon. ${ }^{13}$

Many studies have lighted the inappropriate use of selfmedication which leads to irrational medicine use postponing the right treatment and enhancing ADRs. ${ }^{14}$

This study focuses on the pattern and attitude of women (housewives/ working) towards self- medication and influence of working atmosphere and exposure of women on self-medication.

Women are primarily responsible for the health needs of the family and self- medication is frequently practiced by them. They are the centre of the family tree and all the members look forward to them for the fulfilment of the various needs and chores. Health is one of the concepts of prime concern in a family. Whether child or old people, all are prone to various diseases off and on and it's only the women of the family who look after them. With time and experience they gain an abundant knowledge of various remedies, drugs and therapies. Hence, they form the study population of this study.

\section{METHODS}

It's an observational cross-sectional study. A sample size of total 170 women (working and non-working housewives) within age group of 18-60 years was taken for the study done in urban areas of city of Southern Rajasthan from July 2017 to November 2017. ${ }^{15}$ A semi structured detailed questionnaire was prepared and filled by the subjects under observation of investigator. Prior written informed consent was obtained from them. Ethical committee approval was also obtained.

The data obtained was analysed by using Microsoft excel software and Fischer exact test. Variables like age, education, family income, marital status, occupation, mass media exposure and adverse effects were studied. Practices of self-medication among women were analysed. An
Interview schedule was prepared in English Language and then translated into local i.e. Hindi language for convenience of household women. ${ }^{15,16}$

The tool was divided into two parts, sample characteristics, which consisted of age, education, occupation \& mass media exposure. Second part of tool was the checklist to assess practices of self-medication and adverse effects. This part consisted of need for self-medication, medicine practiced for self-medication, analyse the drug used and check various safety measures regarding it. Content validity of the tool was determined by expert's opinion and suggestions.

\section{Inclusion criteria}

Total no of 170 women (working and non-working housewives) in the age group of 18 to 60 years were selected and divided in two groups:

- Group A: Housewives with minimum qualification graduation.

- Group B: Working women with minimum qualification graduation.

\section{Exclusion criteria}

All women related to medical/paramedical fields, below 18 years and unmarried, women above 60 years.

\section{Data analysis}

The prevalence of self-medication is reported as percentages. Various determinants of self-medication use were analyzed using Fisher's exact test using. The $\mathrm{P}$ $<0.0001$ was taken as statistically significant.

\section{RESULTS}

The result reflects the various differences in pattern, attitude and behaviour of working and non-working women on the practice of self-medication. How education, exposure to working atmosphere influences or affects this practice of self-medication is reflected in this study.

There were $15.38 \%$ of house wives responded that they always prefer to consult doctor when they fall sick as compare to $34.48 \%$ of working women.

Sources from where women get information about selfmedication were mainly their old experience, media, family members and friends and chemist. There was significant difference in the response (Figure 1).

Most common reason for self-medication in our study was pain for both the groups, other reasons were headache, fever, cough and cold (Figure 2). There was marked differences in preference percentages of various drugs used by housewives and working women for various day to day ailments (Table 1). 
Table 1: Various medicinal preferences in percentage as stated by housewives and working women for various common ailments during self-medication.

\begin{tabular}{|c|c|c|c|c|}
\hline & Housewives & $\%$ Preference & Working & $\%$ Preference \\
\hline \multirow{7}{*}{ Headache } & 1.Ibuprofen and paracetamol & 33.33 & \multirow{2}{*}{$\begin{array}{l}\text { 1.Combination of } \\
\text { paracetamol, caffeine and } \\
\text { phenazone }\end{array}$} & \multirow[b]{2}{*}{41.50} \\
\hline & 2.Paracetamol+caffiene+phenazone & 30.76 & & \\
\hline & 3.Ibuprofen & 12.82 & 2.Ibuprofen+paracetamol & 33.96 \\
\hline & 4.Aspirin+codeine $\mathrm{PO} 4$ & 10.38 & 3.Aspirin+codeine PO4 & 18.86 \\
\hline & $\begin{array}{l}\text { 5.Paracetamol+caffeine+ } \\
\text { phenylephine }\end{array}$ & 7.69 & \multirow{3}{*}{$\begin{array}{l}\text { 4.Paracetamol+caffiene+phe } \\
\text { nylephrine }\end{array}$} & \multirow{3}{*}{5.66} \\
\hline & 6.Paracetamol+caffiene+phenazone & 2.56 & & \\
\hline & 7.Methyl salicylate ointment & 2.56 & & \\
\hline Anxiety & Pudin hara & 100 & nil & nil \\
\hline \multirow{6}{*}{$\begin{array}{l}\text { Stomach } \\
\text { acidity }\end{array}$} & 1.Ranitidine & 54.16 & 1.Ranitidine & 53.84 \\
\hline & 2.Pantoprazole sod+sisquihydrate & 26.38 & $\begin{array}{l}\text { 2. Pantoprazole } \\
\text { sod+sesquihydrate }\end{array}$ & 25.64 \\
\hline & \multirow{2}{*}{$\begin{array}{l}\text { 3.Sodbi carbonate+citricacid }+ \text { sod } \\
\text { carbonate }\end{array}$} & \multirow{2}{*}{11.11} & 3.Pantoprazole & 7.69 \\
\hline & & & \multirow{2}{*}{$\begin{array}{l}\text { 4. Sodbicarbonate+citricacid } \\
\text { +sod carbonate }\end{array}$} & \multirow{2}{*}{7.69} \\
\hline & \multirow{2}{*}{$\begin{array}{l}\text { 4.Polydimethyl siloxane+dried al } \\
\text { hydrate+magnesium al } \\
\text { silicate+magnesium hydrate }\end{array}$} & \multirow{2}{*}{8.33} & & \\
\hline & & & 5.Pudin satva & 5.12 \\
\hline \multirow{2}{*}{ Vomiting } & \multirow{2}{*}{ Ondensetron } & \multirow{2}{*}{100} & 1.Ondansetron & 50 \\
\hline & & & 2.Loperamide & 50 \\
\hline \multirow{5}{*}{ Fever } & 1.Paracetamol & 41.17 & 1.Paracetamol & 61.36 \\
\hline & 2.Ibuprofen+paracetamol & 31.37 & 2.Ibuprofen+paracetamol & 18.18 \\
\hline & 3.Ibuprofen & 15.68 & \multirow{2}{*}{$\begin{array}{l}\text { 3.Paracetamol+caffiene+ } \\
\text { phenylephrine }\end{array}$} & \multirow{2}{*}{13.63} \\
\hline & 4.Paracetamol+caffiene+ & & & \\
\hline & phenylephrine & $11 . / 6$ & 4.Nimesulide & 6.81 \\
\hline \multirow{4}{*}{$\begin{array}{l}\text { Cough and } \\
\text { cold }\end{array}$} & $\begin{array}{l}\text { 1. Paracetamol in combination with } \\
\text { caffeine and phenylephrine }\end{array}$ & 30.18 & 1.Cetirizine & 58.33 \\
\hline & 2.Cetrizine & 20.75 & 2.Diphenhydramine & 20.83 \\
\hline & 3.Diphenhydramine & 30.18 & \multirow{2}{*}{$\begin{array}{l}\text { 3.Paracetamol in } \\
\text { combination with caffeine } \\
\text { and phenylephrine }\end{array}$} & \multirow[b]{2}{*}{20.83} \\
\hline & 4.Camphor, eucalyptus oil, menthol & 18.86 & & \\
\hline $\begin{array}{l}\text { Sleepless- } \\
\text { ness }\end{array}$ & Alprazolam (less frequency) & 100 & $\begin{array}{l}\text { Alprazolam (more } \\
\text { frequency) }\end{array}$ & 100 \\
\hline \multirow{2}{*}{$\begin{array}{l}\text { Simple } \\
\text { wound } n \\
\text { cuts }\end{array}$} & \multirow{2}{*}{ Betadine } & \multirow{2}{*}{100} & 1.Betadine & 76.92 \\
\hline & & & 2.Soframycin & 23.07 \\
\hline \multirow{4}{*}{ Bodyache } & 1.Ibuprofen with paracetamol & 70 & \multirow{4}{*}{ Ibuprofen with paracetamol } & \multirow{4}{*}{100} \\
\hline & 2.Ibuprofen & 10 & & \\
\hline & 3.Diceclofenac & 10 & & \\
\hline & $\begin{array}{l}\text { 4.Paracetamol+caffiene+ } \\
\text { phenylephrine }\end{array}$ & 10 & & \\
\hline \multirow{2}{*}{ High bp } & 1.Losartan & 80 & losartan & 100 \\
\hline & 2.metoprolol & 20 & Iosartan & \\
\hline $\begin{array}{l}\text { Energy } \\
\text { giving }\end{array}$ & $\begin{array}{l}\text { Energy giving supplements ( } 25 \% \text { of } \\
\text { total i.e. Less frequently) }\end{array}$ & 100 & $\begin{array}{l}\text { Energy giving supplements } \\
\text { ( } 75 \% \text { of total more } \\
\text { frequently) }\end{array}$ & 100 \\
\hline Others(dysm & 1.Dicyclomine, mefanamic acid, & 60 & 1.Dicyclomine, & 100 \\
\hline enorrhoea) & 2. pheniramine & 40 & mefanamic acid & 100 \\
\hline
\end{tabular}

Consequently, there was marked difference in medicines kept at households for self-medication. For pain, housewives preferred flexon, ibuprofen, crocin, flexon and paracetamol combination, combiflam, combiflam and 
saridon. On the other hand, working women preferred flexon, disprin, crocin, combination of disprin and flexon, meftal spas, saridon.

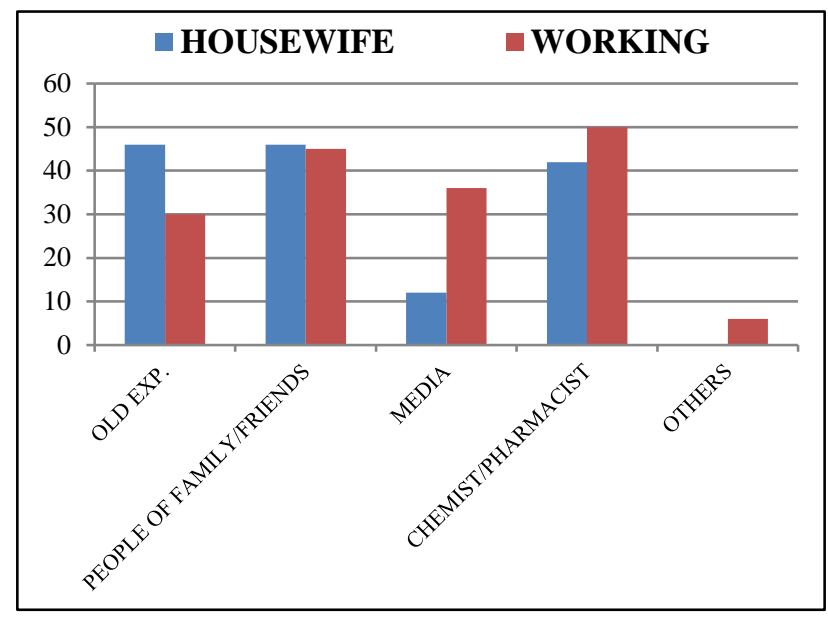

Figure 1: Various sources of information to housewives and working women for self medication.

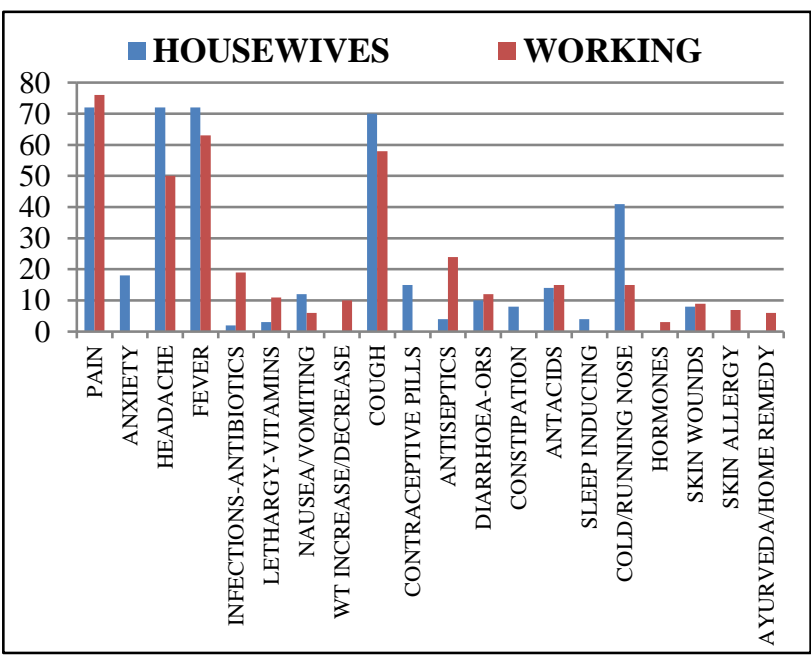

Figure 2: Various medicines or combinations of medicines used by housewives and working women for various common ailments.

For cough and cold housewives mainly relied upon cetirizine, vicks, dcoldtotal, benadryl, cetzine+vicks+Benadryl. Choice of working women for the same ailment included vicks, vicks action 500, cozyplus, dotarin+ridol, cetzine+Benadryl.

For other miscellaneous diseases like stomach acidity, housewives preferred ranitidine and pantoprazole while for simple cuts and wounds, working women preferred soframycin, Dettol, Savlon and betadine.

Working women checked expiry date more frequently $(100 \%)$, than housewives $(90 \%)(\mathrm{P}=0.0023)$ They also used to read the instruction manual $(90.80 \%)$ as compared to house wives $(10 \%)(\mathrm{P}<0.0001) .86 .66 \%$ of working women were found to be aware of drug interactions as compare to $61.53 \%$ of house wives $(\mathrm{P}<0.0001) .93 .3 \%$ of working women were instructed about the adverse drug reactions of the drug by the chemist as compare to $67.5 \%$ of house wives. $(\mathrm{P}<0.0001) .35 .29 \%$ of working women reported presence of adverse drug reactions after selfmedication as compare to $5.12 \%$ of house wives $(\mathrm{P}<0.0001)$.

There was marked difference in response related to action taken after observing adverse drug reaction (Figure 3), where working women consulted physician and house wives relied on other household remedies.

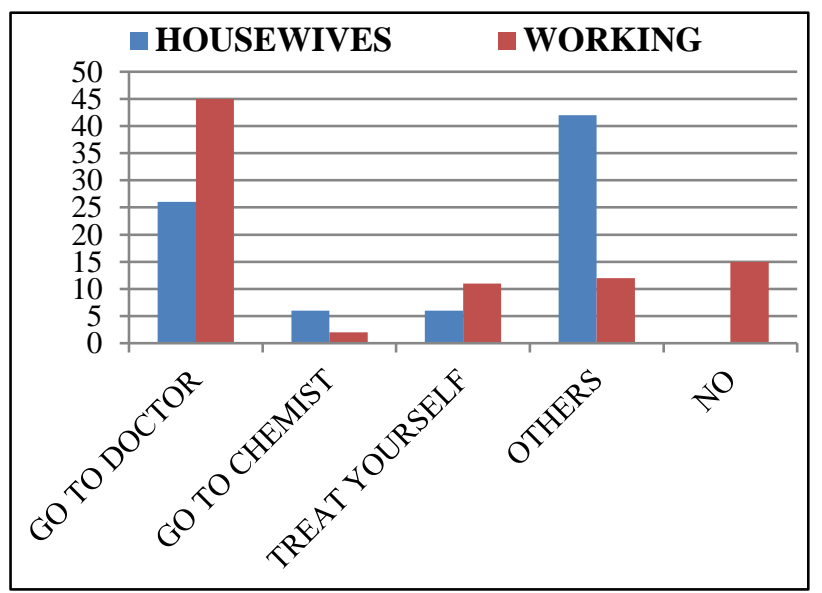

Figure 3: Different steps taken by housewives or working women after observing adverse drug reactions of self-medication.

There were $58.62 \%$ of working women were concerned they could have taken counterfeit medicine also while house wives were totally unaware of this fact $(\mathrm{P}<0.0001)$. $100 \%$ of working women and $74.7 \%$ of working women agreed to recommend the same treatment to others

All the respondents of both groups $(100 \%)$ found selfmedication beneficial. Housewives, in more number $(46.34 \%)$ reported that they stopped the use of medicine when symptoms disappeared; on the contrary working women $(61.1 \%)$ stopped the drug use after few days of recovery. Almost all $(100 \%)$ of housewives agreed to recommend the same treatment to others as compared to less number of working women $(74.71 \%)(\mathrm{P}<0.0001)$.

\section{DISCUSSION}

Regarding sources of information about self-medication, house wives relied more on old experience while working women on chemist and pharmacists. Working women also included media as a source of information significantly (Figure 1). This may be due to more exposure of working women to media and more interest in acquiring appropriate knowledge from persons related to medicines. In study by Sangeeta et $\mathrm{al}^{8}$, women used magazines as a primary source of information and in study by Gurmit et al, maximum women used television as source of 
information. ${ }^{16}$ The difference may be due to inclusion of all women with minimum graduation qualification and division of respondents into two groups as working and nonworking in our study. This division is not found in any of the studies available.

Reasons or ailments for self-medication, restricted to housewives were anxiety, contraceptive use and constipation. While working women were exclusively using medicines for sleep induction, hormones, weight reduction, skin allergies. This indicate influence of working environment on various daily routine patterns like sleep, stress level, weight management and exposure to allergens. The results were very similar to reasons found in other studies. ${ }^{16}$

For headache, more respondents from the working women group took combination of analgesic containing caffeine, and for cough and cold they relied on cetrizine rather than combination containing paracetamol, caffeine and phenylephrine indicates their awareness about sedating nature of antihistamines and safety of cetrizine. Surprisingly working women used loperamide for vomiting and housewives used pudin hara for anxiety. Housewives had misperception of anxiety and related it to stomach upset. This indicates need of proper guidance and sensitization of women for safe use of medicine and adverse drug reactions. They should be well informed about the unnecessary use of medicines. This also shows incomplete knowledge provided by the media.

Working women were found to be more aware of adverse drug reactions and drug interactions and this may be the reason, they carefully read the instruction manual and checked the expiry date and asked the chemist for adverse drug reaction. This indicates that working environment and exposure increases concern about safe and responsible self-medication. Working women stopped drug usage few days after recovery indicating more care and concerns in contrary to housewives. Almost all housewives agreed to refer their self-medication treatment to their known subjects as compared to less number of working women. It shows an awareness and cautious observing behaviour of working women that one kind of treatment may/maynot be effective in some other person.

The study was limited to two groups and did not include associated factors like type of employment, type of family, nuclear or joint or availability of health care facility in that area. The study can be further expanded to analyse any influence of these factors on pattern of self-medication and attitude of women for self-medication. Which may further throw light in depth regarding the different concerns of self-medication of the two groups

\section{CONCLUSION}

Self-medication is very common amongst women due to lack of time, easy availability of medicines, work load and non-availability of health care facilities every time. It also reduces health expenditure, but it is not a safe practice, may cause incorrect diagnosis, adverse drug reactions and drug interactions. In our study both working women and house wives were found to be indulged in self-medication related to variety of symptoms which may lead to misdiagnosis or incorrect diagnosis

Most common reason for self-medication was pain and the drugs used were analgesics. The study reveals that the working environment and exposure influence the pattern and attitude of women towards self-medication. Working women were more aware of safe self-medication and concern about expiry date of the drug, drug manual, adverse drug reactions and drug interactions.

Study reveals need of education related to safe use of medicines, strict regulatory actions regarding over the counter availability of drugs.

The study can further be expanded with larger sample size to analyze influence of associated factors like nuclear or joint family, type of employment and availability of health care facility and its distance from household.

This study will provide useful, descriptive and informative insight on the various reasons for which both the groups of women resorted to this practice of self-medication and might help the policy makers and regulatory authorities to streamline the process of drug regulations, to update the list of essential medicines, and revaluate the various safety issues of over the counter drugs.

Funding: No funding sources

Conflict of interest: None declared

Ethical approval: The study was approved by the Institutional Ethics Committee

\section{REFERENCES}

1. A World Health Organization resource: the role of pharmacist in self- care and self-medication; 1998:17. Available

at: http://apps.who.int/medicinedocs/en/d/Jwhozip32e/co accessed November 2013.

2. World Self Medication Industry declaration. Available at: URL http://www.wsmi.org/declaration.html.

3. Rambhade S, Chakarborty A, Shrivastava A, Patil UK, Rambhade A. Asurvey on polypharmacy and use of inappropriate medicaations. Toxicol. Int. 2012;19(1):68-73.

4. World Medical Association. Statement on Self Medication. Available at: http://www.chpainfo. org/issues/WMA_SelfMedication.aspx.

5. Responsible self care and self medication. A world wide review of consumer surveys. World self Medication Industry. Available at: www.wsmi.org/pdf/wsmibro3.pdf.

6. Guidelines for regulatory assessment of medicinal products for use in self medication, WHO, Geneva; 
2000.

Available

at:

http://archives.who.int/tbs/qual/s2218e.pdf.

7. Wazaify M, Shields E, Hughes CM, McElnay JC. Societal perspectives on over-the-counter (OTC) medicines. Family Practice. 2005;22:170-6.

8. Nair MGS, Rajmohanan TP, Kumaran J. Self Medication Practices of Reproductive Age Group Women in Thiruvananthapuram District, South India: A Questionnaire - Based Study. J Pharm Sci Res. 2013;5(11):220-5.

9. Chaturvedi HK, Mahanta J, Pandey A. Treatmentseeking for febrile illness in North-East India: An epidemiological study in the malaria endemic zone. Malar J. 2009;8:301. [PMC free article] PubMed.

10. WHO. What influences drug use by consumers promoting rational use in the community. Geneva; 1993. Available at: www.WHO.int.

11. Nuralia AU, Athijah U, Nita Y. Analysis of factors influencing Self-medication behaviours by housewives (Study of common cold cases in Semolowaru, Surabaya). Mal J Pharmaceu Scienc. 2005;3(2):74-5.

12. Itterman RD, Johnson JA, Taylor JG. Health status and self-medication patterns in Alberta, Canada. Results from a population health survey. J Soc Administrat Pharma. 2003;20(2):43-52.
13. Huges CM, Mc Elnay JC, Fleming GF. Benefits and risks of self medication. Drug Safety. 2001;24:102734.

14. Schmiedl S, Rottenkolber M, Hasford J, Rottenkolber D, Farker K, Drewelow B, et al. Self-medication with over-the-counter and prescribed drugs causing adverse-drug-reaction-related hospital admissions: results of a prospective, long-term multi-centre study. Drug Saf. 2014 Apr;37(4):225-35.

15. Selvaraj K, Kumar G, Ramalingam A. Prevalence of self-medication practices and its associated factors in Urban Puducherry, India Perspect Clin Res. 2014 JanMar;5(1):32-6.

16. Kaur G, Glory S, Kaur J. An exploratory study to assess the practices of self-medication among women in a selected Community of Ludhiana, Punjab. Nur Midwife Res J. 2011 July;7(3):122.

Cite this article as: Atray M, Radhika V. Pattern of self-medication amongst housewives vs working women in urban population in Southern Rajasthan. Int J Basic Clin Pharmacol 2018;7:1561-6. 